\title{
Comparative Study of the Efficiency of Different Noble Metals Supported on Hydroxyapatite in the Catalytic Lean Methane Oxidation under Realistic Conditions
}

\author{
Zouhair Boukha *, Beatriz de Rivas, Juan R. González-Velasco, José I. Gutiérrez-Ortiz and Rubén López-Fonseca \\ Chemical Technologies for Environmental Sustainability Group, Chemical Engineering Department, Faculty of \\ Science and Technology, University of The Basque Country UPV/EHU, 48940 Leioa, Bizkaia, Spain; \\ beatriz.derivas@ehu.eus (B.d.R.); juanra.gonzalezvelasco@ehu.eus (J.R.G.-V.); \\ joseignacio.gutierrez@ehu.eus (J.I.G.-O.); ruben.lopez@ehu.eus (R.L.-F.) \\ * Correspondence: zouhair.boukha@ehu.eus
}

check for

updates

Citation: Boukha, Z.; de Rivas, B.; González-Velasco, J.R.;

Gutiérrez-Ortiz, J.I.; López-Fonseca,

R. Comparative Study of the

Efficiency of Different Noble Metals Supported on Hydroxyapatite in the Catalytic Lean Methane Oxidation under Realistic Conditions. Materials 2021, 14, 3612. https://doi.org/ $10.3390 / \mathrm{ma} 14133612$

Academic Editor: Lucjan Chmielarz

Received: 25 May 2021

Accepted: 23 June 2021

Published: 28 June 2021

Publisher's Note: MDPI stays neutral with regard to jurisdictional claims in published maps and institutional affiliations.

Copyright: (C) 2021 by the authors Licensee MDPI, Basel, Switzerland. This article is an open access article distributed under the terms and conditions of the Creative Commons Attribution (CC BY) license (https:/ / creativecommons.org/licenses/by/ $4.0 /)$.

\begin{abstract}
The combustion of lean methane was studied over palladium, rhodium, platinum, and ruthenium catalysts supported on hydroxyapatite (HAP). The samples were prepared by wetness impregnation and thoroughly characterized by BET, XRD, UV-Vis-NIR spectroscopy, $\mathrm{H}_{2}$-TPR, OSC, CO chemisorption, and TEM techniques. It was found that the Pd/HAP and Rh/HAP catalysts exhibited a higher activity compared with Pt/HAP and Ru/HAP samples. Thus, the degree of oxidation of the supported metal under the reaction mixture notably influenced its catalytic performance. Although $\mathrm{Pd}$ and $\mathrm{Rh}$ catalysts could be easily re-oxidized, the re-oxidation of $\mathrm{Pt}$ and $\mathrm{Ru}$ samples appeared to be a slow process, resulting in small amounts of metal oxide active sites. Feeding water and $\mathrm{CO}_{2}$ was found to have a negative effect, which was more pronounced in the presence of water, on the activity of Pd and Rh catalysts. However, the inhibiting effect of $\mathrm{CO}_{2}$ and $\mathrm{H}_{2} \mathrm{O}$ decreased by increasing the reaction temperature.
\end{abstract}

Keywords: noble metals; hydroxyapatite; lean methane oxidation; $\mathrm{OSC}$; water and $\mathrm{CO}_{2}$ effects

\section{Introduction}

The implementation of strict environmental regulations imposes the use of more efficient and cleaner fuels. In this sense, the utilization of lean burn natural gas (NG) engines is one of the most attractive strategies compared to those based on gasoline or diesel [1-6]. In addition to its high calorific value, the combustion of this fuel results in advantageous $\mathrm{CO}_{2}$ emissions and emits lower levels of toxic $\mathrm{CO}$ and $\mathrm{NO}_{\mathrm{x}}$. However, the release of unburnt methane presents a significant problem that contributes to the greenhouse effect. Though it is less abundant in the atmosphere, methane is significantly more active in trapping radiation than $\mathrm{CO}_{2}$.

As a result, it is essential that active and durable catalysts are developed for $\mathrm{CH}_{4}$ emission abatement. It is known that noble metals exhibit a high activity and good resistance to coke formation [1,4-7]. Among the noble metals, Pd-based catalysts supported on alumina are clearly the most investigated systems. Nevertheless, few catalysts have demonstrated a reasonable activity and long-term stability under realistic reaction mixtures, in the presence of large amounts of $\mathrm{H}_{2} \mathrm{O}(10-15 \%)$ and $\mathrm{CO}_{2}(10-15 \%)$, and trace levels of sulfur compounds $\left(\mathrm{SO}_{2}\right.$ or $\left.\mathrm{H}_{2} \mathrm{~S}\right)$ present in the exhaust gas of $\mathrm{NG}$ engines [4]. To address these major disadvantages, current research is focused on the use of alternative supports that present suitable interactions with the active phase [1,2,6-9]. Similarly, various promoters and bimetallic formulations have been examined to improve the activity and the resistance of the catalysts [10-13].

Numerous reports have claimed that the oxidation state of the catalyst plays a key role in controlling its performance for methane oxidation. There is broad consensus that the active sites are generally composed of the metal oxide $[1,4,7,13]$. However, the occurrence 
of oxygen vacant sites in the proximity of the active phase or at the metal-support interface also seems to be extremely important. This confers to the catalyst a significant ability to undergo redox process and oxygen mobility, in accordance with the Mars-Van Krevelen mechanism. Cullis et al. [13] demonstrated that the nature of the used support influenced the ability of noble metals to adsorb oxygen, and there was a correlation between the oxygen adsorption capacity of the supported precious metal and its catalytic activity for methane oxidation.

Due to their distinct properties, HAP materials have attracted considerable attention as catalyst supports for numerous applications [14-24]. Previous reports noted that the advantage of the use of HAP as a support lies in its capacity to retain its structural properties when it undergoes significant changes in composition $[7,24]$. The promising results arising from the use of HAP were found to be connected to its high thermal stability, acid-base properties, and the fact that it could provide beneficial synergistic effects with a variety of metallic active phases [14-24].

In the present study, we examined the suitability of HAP as a support for a series of noble metal catalysts ( $\mathrm{Pd}, \mathrm{Rh}, \mathrm{Pt}$ and $\mathrm{Ru}$ ) for the methane oxidation reaction. The catalysts were extensively characterized by BET, XRD, TEM, $\mathrm{H}_{2}$-TPR, UV-Vis-NIR spectroscopy, CO chemisorption, and OSC techniques to correlate their activity with the structural features. To the best of our knowledge, no similar comparative study has been conducted on the activity of the series of noble metal catalysts supported on HAP.

\section{Materials and Methods}

\subsection{Preparation of the Catalysts}

The HAP support was synthesized using the co-precipitation method, adding drop wise a calcium nitrate solution to a solution of $\left(\mathrm{NH}_{4}\right)_{2} \mathrm{HPO}_{4}$ in a basic medium $(\mathrm{pH}=10)$. Under stirring, the mixture was heated to $80^{\circ} \mathrm{C}$ and then maintained for $16 \mathrm{~h}$ to accelerate its crystallization process. After filtration, the recovered solid was washed with distilled water, dried overnight at $120^{\circ} \mathrm{C}$, and then calcined in static air at $500{ }^{\circ} \mathrm{C}$ for $4 \mathrm{~h}$.

The noble metal catalysts (Pd/HAP, Rh/HAP, $\mathrm{Pt} / \mathrm{HAP}$, and $\mathrm{Ru} / \mathrm{HAP}$ ), with a metal loading of $0.5 \mathrm{wt} . \%$, were prepared by incipient wetness impregnation of the support with aqueous solutions of the respective precursor salts; namely $\mathrm{Pd}\left(\mathrm{NH}_{3}\right)_{4} \mathrm{Cl}_{2} \cdot \mathrm{H}_{2} \mathrm{O}, \mathrm{RhCl}_{3} \cdot 3 \mathrm{H}_{2} \mathrm{O}$, $\left[\mathrm{Pt}\left(\mathrm{NH}_{3}\right)_{4}\right]\left(\mathrm{NO}_{3}\right)_{2}$, and $\mathrm{Ru}(\mathrm{NO})\left(\mathrm{NO}_{3}\right)_{3}$, respectively. The impregnated samples were dried overnight at $120^{\circ} \mathrm{C}$ and then calcined at $500^{\circ} \mathrm{C}$ for $4 \mathrm{~h}$.

\subsection{Characterization Techniques}

The textural properties of the prepared catalysts were investigated by $\mathrm{N}_{2}$ physisorption experiments at $-196{ }^{\circ} \mathrm{C}$ on a Micromeritics (TRISTAR II 3020) apparatus (Micromiritics Instrument Corp, Norcross, GA, USA). Prior to analysis, the samples were purged with $\mathrm{N}_{2}$ flow at $300{ }^{\circ} \mathrm{C}$ for $8 \mathrm{~h}$. The structural properties were investigated by XRD. The analyses were performed on a X'PERT-MPD X-ray instrument (Malvern Panalytical Ltd., Royston, UK). The coordination and the oxidation state of the metallic species were studied by diffuse reflectance UV-Vis-NIR spectroscopy with a Cary 5000 apparatus (Agilent Technologies, Santa Clara, CA, USA).

Temperature-programmed reduction with hydrogen $\left(\mathrm{H}_{2}\right.$-TPR) experiments were carried out on a Micromeritics AutoChem 2920 apparatus (Micromiritics Instrument Corp. Norcross, GA, USA). The samples were pre-treated in a flow of $5 \% \mathrm{O}_{2} / \mathrm{He}$ at $500{ }^{\circ} \mathrm{C}$ for $30 \mathrm{~min}$ and then cooled to $-30{ }^{\circ} \mathrm{C}$ in He. Finally, they were reduced in $5 \% \mathrm{H}_{2} / \mathrm{Ar}$ gas flow $\left(50 \mathrm{~cm}^{3} \mathrm{~min}^{-1}\right)$ by increasing the temperature from -30 to $750{ }^{\circ} \mathrm{C}$ with a ramp of $10{ }^{\circ} \mathrm{C} \mathrm{min}^{-1}$.

The size and dispersion of the metallic particles for the reduced samples were investigated by transmission electron microscopy (TEM). The observations were performed on a TECNAI G2 20 TWIN microscope (FEI Company, Hillsboro, OR, USA) operated at $200 \mathrm{kV}$ and equipped with a LaB6 filament. The metallic dispersion was also estimated by $\mathrm{CO}$ chemisorption at $40^{\circ} \mathrm{C}$ using the same instrument used for $\mathrm{H}_{2}$-TPR studies. The 
samples were pre-reduced by flowing $5 \% \mathrm{H}_{2} / \mathrm{Ar}\left(50 \mathrm{~cm}^{3} \mathrm{~min}^{-1}\right)$ at $400{ }^{\circ} \mathrm{C}$ for $1 \mathrm{~h}$. Then, they were cooled under He flow to $40{ }^{\circ} \mathrm{C}$ and submitted to a series of CO pulses (using $5 \% \mathrm{CO} / \mathrm{He}$ and a loop volume of $0.5 \mathrm{~cm}^{3}$ ) until their saturation. The metallic dispersion, defined as the exposed active metal fraction, was determined on the assumption of a unity adsorption stoichiometry.

The oxygen storage capacity (OSC) for the synthesized samples was studied by oxygen volumetric chemisorption in the temperature range of $350-500{ }^{\circ} \mathrm{C}$ on a Micromeritics AutoChem 2920 instrument (Micromiritics Instrument Corp. Norcross, GA, USA). The samples $(100 \mathrm{mg})$ were pre-reduced with a flow of $5 \% \mathrm{H}_{2} / \mathrm{Ar}\left(50 \mathrm{~cm}^{3} \mathrm{~min}^{-1}\right)$ at $500{ }^{\circ} \mathrm{C}$ for $1 \mathrm{~h}$ and, then, evacuated in He for $1 \mathrm{~h}$. After their cooling to the analysis temperature, they were submitted to twenty $\mathrm{O}_{2}$ pulses $\left(5 \% \mathrm{O}_{2} / \mathrm{He}\right.$, loop volume: $\left.0.5 \mathrm{~cm}^{3}\right)$, injected in He carrier $\left(50 \mathrm{~cm}^{3} \mathrm{~min}^{-1}\right)$.

\subsection{Catalytic Performance Testing}

The catalytic runs were carried out in a fixed-bed reactor operating at atmospheric pressure. The catalysts $(200 \mathrm{mg}, 160-250 \mu \mathrm{m})$ diluted with quartz particles were pretreated under a $5 \% \mathrm{O}_{2} / \mathrm{He}$ flow $\left(100 \mathrm{~cm}^{3} \mathrm{~min}^{-1}\right)$ at $500{ }^{\circ} \mathrm{C}$ for $1 \mathrm{~h}$. The standard reaction mixture was composed of $1 \% \mathrm{CH}_{4}$ and $20 \% \mathrm{O}_{2}$ balanced with $\mathrm{He}\left(\mathrm{F}_{\text {tot }}=100 \mathrm{~cm}^{3} \mathrm{~min}^{-1}\right)$ corresponding to a weight hourly space velocity (WHSV) of $300 \mathrm{~cm}^{3} \mathrm{CH}_{4} \mathrm{~h}^{-1} \mathrm{~g}^{-1}$. The reaction temperature was increased from 200 to $500{ }^{\circ} \mathrm{C}$ with a ramp of $1^{\circ} \mathrm{C} \mathrm{min}{ }^{-1}$. The thermocouple was positioned at the inlet of the catalyst bed. Additional experiments were performed to study the influence of the addition of water $(10 \%)$ and $\mathrm{CO}_{2}(10 \%)$. The water vapor was fed using a GILSON 307 pump (Gilson Inc., Middleton, OR, USA). The analysis system consisted of a gas chromatograph (Agilent Technologies 490 Micro GC) (Agilent Technologies, Santa Clara, CA, USA) equipped with a TCD detector.

\section{Results}

\subsection{Characterization of the Catalysts}

The $\mathrm{N}_{2}$ adsorption/desorption isotherms corresponding to the bare support and the four noble metal-modified samples, respectively, are presented in Supplementary Materials Figure S1. All samples exhibit similar shapes of both the isotherms and hysteresis loops. The adsorption branches are analogous to those of type II whereas the desorption isotherms present a hysteresis loop of H3, typically found over aggregates presenting slit-shaped pores. Data from Table 1 reveal that the modification of the HAP support with the noble metals does not provoke significant changes in its textural properties. The measured specific surface areas were found to range between 48 and $53 \mathrm{~m}^{2} \mathrm{~g}^{-1}\left(55 \mathrm{~m}^{2} \mathrm{~g}^{-1}\right.$ for the bare support).

Table 1. Characterization data of the noble metal catalysts.

\begin{tabular}{|c|c|c|c|c|c|c|}
\hline \multirow{2}{*}{ Sample } & \multicolumn{3}{|c|}{ BET } & \multicolumn{3}{|c|}{$\mathrm{H}_{2}-\mathrm{TPR}$} \\
\hline & $\mathrm{S}_{\mathrm{BET}}, \mathrm{m}^{2} \mathrm{~g}^{-1}$ & $V_{p}{ }^{(a)}, \mathrm{cm}^{3} \mathrm{~g}^{-1}$ & $\mathrm{~d}_{\mathrm{p}}(\mathrm{b}), \mathrm{nm}$ & $\operatorname{mmol}_{\mathrm{H} 2} \mathrm{~g}^{-1}$ & $\left(\mathrm{H}_{2} / \mathrm{M}\right)^{(\mathrm{c})}$ & $\left(\mathrm{H}_{2} / \mathrm{M}\right)^{(\mathrm{d})}$ \\
\hline HAP & 55 & 0.40 & 27.8 & - & - & - \\
\hline $\mathrm{Pd} / \mathrm{HAP}$ & 53 & 0.35 & 26.5 & $3.810^{-2}$ & 0.8 & 1 \\
\hline Rh/HAP & 51 & 0.40 & 29.7 & $6.210^{-2}$ & 1.3 & 1.5 \\
\hline $\mathrm{Pt} / \mathrm{HAP}$ & 51 & 0.37 & 28.7 & $1.110^{-2}$ & 0.4 & 2 \\
\hline $\mathrm{Ru} / \mathrm{HAP}$ & 48 & 0.36 & 29.1 & $8.710^{-2}$ & 1.8 & 2 \\
\hline
\end{tabular}

(a) Pore volume, as determined by application of the BJH method. ${ }^{(b)}$ Mean pore diameter, as determined by application of the BJH method. (c) Actual $\mathrm{H}_{2} / \mathrm{M}$ molar ratio as determined from the integration of the reduction peaks at $\mathrm{T}<250{ }^{\circ} \mathrm{C}$. (d) Theoretical $\mathrm{H}_{2} / \mathrm{M}$ molar ratio required for the reduction of stoichiometric $\mathrm{PdO}, \mathrm{Rh}_{2} \mathrm{O}_{3}, \mathrm{PtO}_{2}$, and $\mathrm{RuO}_{2}$.

The XRD pattern of the HAP bare support (Figure 1) shows that the positions of all diffraction peaks are identical to those expected for the hydroxyapatite structure (JCPDS 01-082-2956), which crystallizes in an hexagonal system and belongs to the $\mathrm{P}_{3} / \mathrm{m}$ space group. The addition of noble metals $(\mathrm{Pd}, \mathrm{Rh}, \mathrm{Pt}$, and $\mathrm{Ru})$ to the HAP and the successive 
thermal treatment at $500{ }^{\circ} \mathrm{C}$ does not significantly affect the structure of the support and its lattice parameters (Supplementary Materials Table S1). Moreover, no additional diffraction peaks due to the deposited metals are observed, which can be explained by their small amounts $(0.5 \mathrm{wt} . \%)$ and/or their high dispersion.

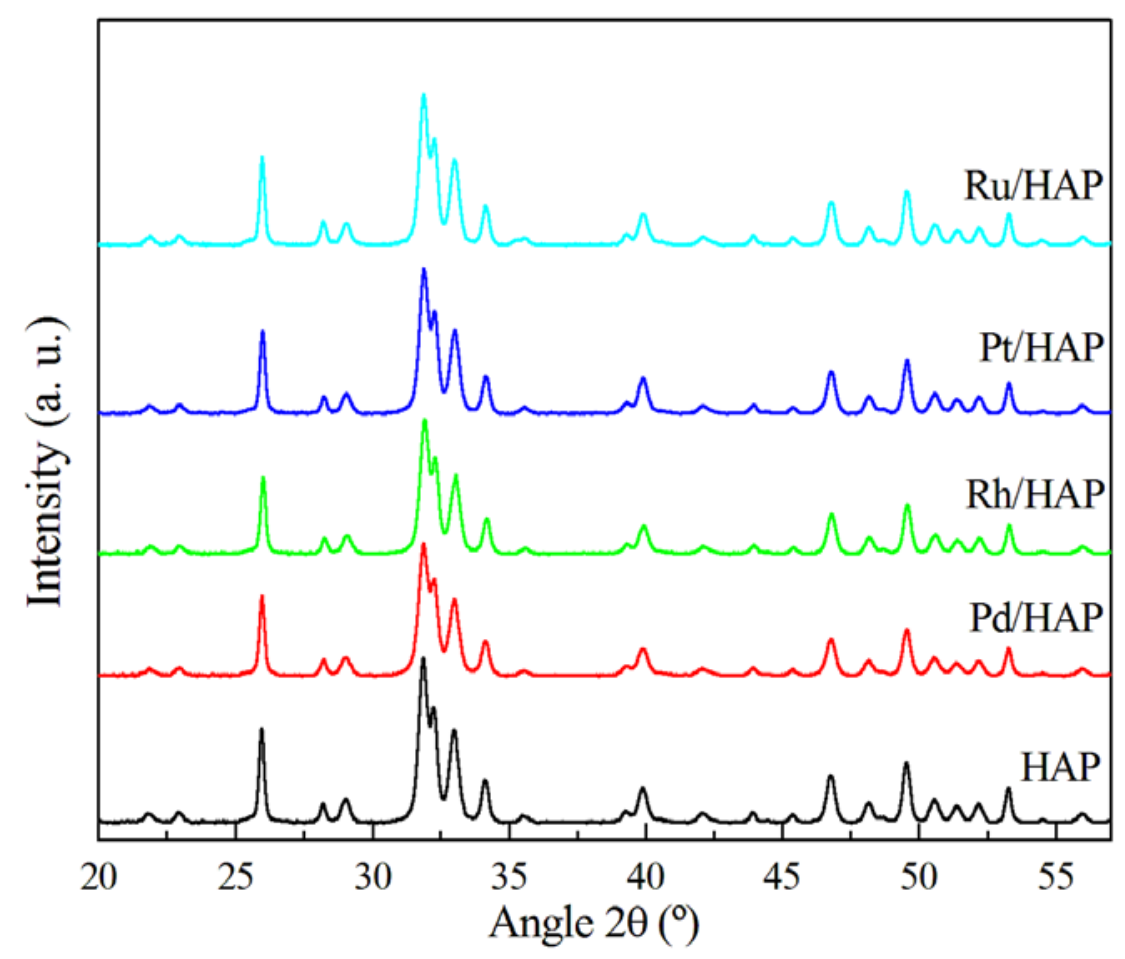

Figure 1. XRD patterns of the noble metal catalysts.

The optical properties of the supported metallic species were investigated using UV-Vis-NIR spectroscopy. Figure 2 shows the corresponding absorption spectra. The spectrum of the HAP support exhibits a strong UV absorption peaked at $200 \mathrm{~nm}$ and a shoulder near $280 \mathrm{~nm}$, assigned to $\mathrm{O}^{2-} \rightarrow \mathrm{Ca}^{2+}$ charge transfers. Irrespective of the nature of the added metal phase, these UV bands appear to intensify markedly, thereby indicating the contribution of $\mathrm{O}^{2-} \rightarrow \mathrm{M}^{\mathrm{x}}$ charge transfers. Moreover, new bands appear in the visible domain due to the $\mathrm{d}$-d transitions of the cationic forms of the impregnated metals. Hence, the Pd/HAP sample exhibits a band centered at $420 \mathrm{~nm}$, assigned to $\mathrm{d}-\mathrm{d}\left(v_{1}+v_{2}\right)$ transitions of $\mathrm{Pd}^{2+}$ ions in a tetrahedral coordination $[1,7]$. The spectrum of the Rh/HAP sample contains a strong absorption peaked at $340 \mathrm{~nm}$ accompanied by a shoulder near $440 \mathrm{~nm}$. According to our previous study, the observed shape and positions indicate the main occurrence of $\mathrm{Rh}_{2} \mathrm{O}_{3}$ species [18]. The spectrum of the Pt/HAP sample is characterized by the presence of a much less intense visible band located at $430 \mathrm{~nm}$, thus suggesting a deposition of relatively smaller amounts of the Pt cationic species. The position of this feature is very close to that observed on the spectrum of a $\mathrm{PtO}_{2}$ phase, as reported by Lietz et al. [25]. The deposition of Ru on the HAP support induces the occurrence of a broad absorption band extended from the visible to the NIR region and peaked at $850 \mathrm{~nm}$. Xiao et al. [26] observed a similar feature, which was assigned to hydrous $\mathrm{RuO}_{2}$ nanoparticles $\left(\mathrm{RuO}_{2} \cdot \mathrm{xH}_{2} \mathrm{O}\right)$. 


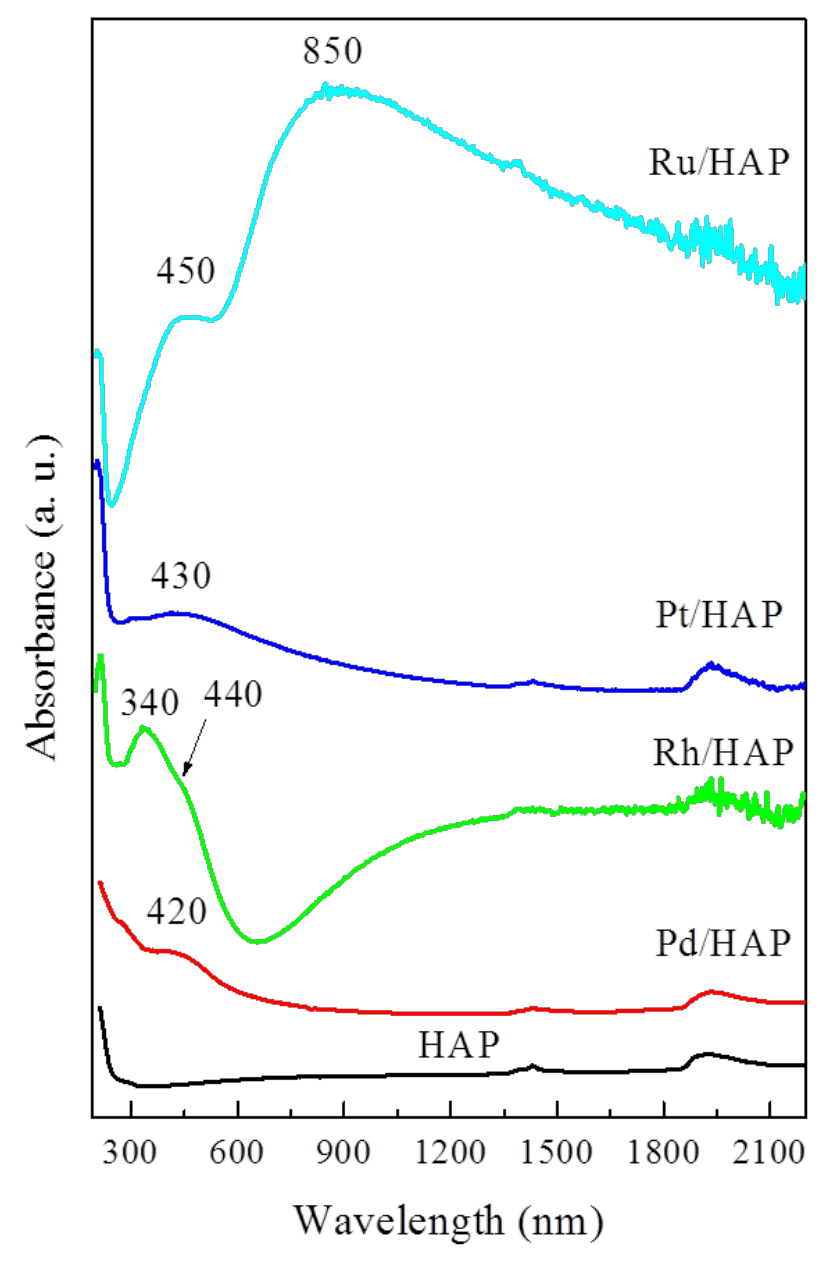

Figure 2. UV-Vis-NIR spectra for the noble metal catalysts.

The reducibility of the prepared catalysts was investigated by $\mathrm{H}_{2}$-TPR. The corresponding profiles and their quantification data are included in Figure 3 and Table 1, respectively. The Pd/HAP catalyst exhibits a typical diagram of the reduction of supported $\mathrm{PdO}$ species [7]. The first uptake, which peaked at $26^{\circ} \mathrm{C}$, is ascribed to the $\mathrm{PdO}$ phase whereas the second, located at $58^{\circ} \mathrm{C}$ (negative peak), is due to the decomposition of palladium hydride ( $\mathrm{Pd}-\mathrm{H})$. The profile of the $\mathrm{Rh} / \mathrm{HAP}$ catalyst presents a broad reduction peak centered at $103{ }^{\circ} \mathrm{C}$. This position is comparable to that found in a previous study on $\mathrm{Rh} / \mathrm{Al}_{2} \mathrm{O}_{3}$ and $\mathrm{Rh} / \mathrm{CeO}_{2}$ systems [27]. In good agreement with the UV-Vis-NIR data, the amounts of consumed $\mathrm{H}_{2}$ suggest that the oxidized $\mathrm{Rh}$ species is mainly composed of the $\mathrm{Rh}_{2} \mathrm{O}_{3}$ phase (Table 1). The $\mathrm{H}_{2}$-TPR profile of the Pt/HAP catalyst is characterized by the presence of a much less intense reduction peak located at $98^{\circ} \mathrm{C}$. Moreover, the estimated $\mathrm{H}_{2} / \mathrm{Pt}$ molar ratio does not exceed 0.4 (Table 1 ). This result could be explained by the presence of additional species, probably exhibiting a strong interaction with the support that require a high reduction temperature [22]. Instead, according to the UV-Vis-NIR data, these results indicate the deposition of relatively small amounts of oxidized Pt species. The $\mathrm{H}_{2}$-TPR profile for the $\mathrm{Ru} / \mathrm{HAP}$ sample displays two reduction peaks located at 97 and $130{ }^{\circ} \mathrm{C}$. These features could be assigned to the reduction of two distinct ruthenium oxide species. Generally, the low temperature peak is attributed to $\mathrm{RuO}_{2}$ phase, whereas the peak at relatively higher temperatures can be associated with Ru species exhibiting a stronger interaction with the support [28]. The quantification of $\mathrm{H}_{2}$ consumption reveals that the calculated $\mathrm{H}_{2} / \mathrm{Ru}$ molar ratio is close to that corresponding to a stoichiometric $\mathrm{RuO}_{2}$ phase (Table 1). It is worth noting that the reduction temperatures of the Ru species found on our $\mathrm{Ru} / \mathrm{HAP}$ sample are significantly lower than those observed on other catalyst supports [28,29]. Lanza et al. [29] attributed this effect to the occurrence of easily reducible 
species $\left(\mathrm{RuO}_{2-\mathrm{y}}(\mathrm{OH})_{y}\right)$, resulting from the interaction of the $\mathrm{RuO}_{2}$ species with surface hydroxyl groups.

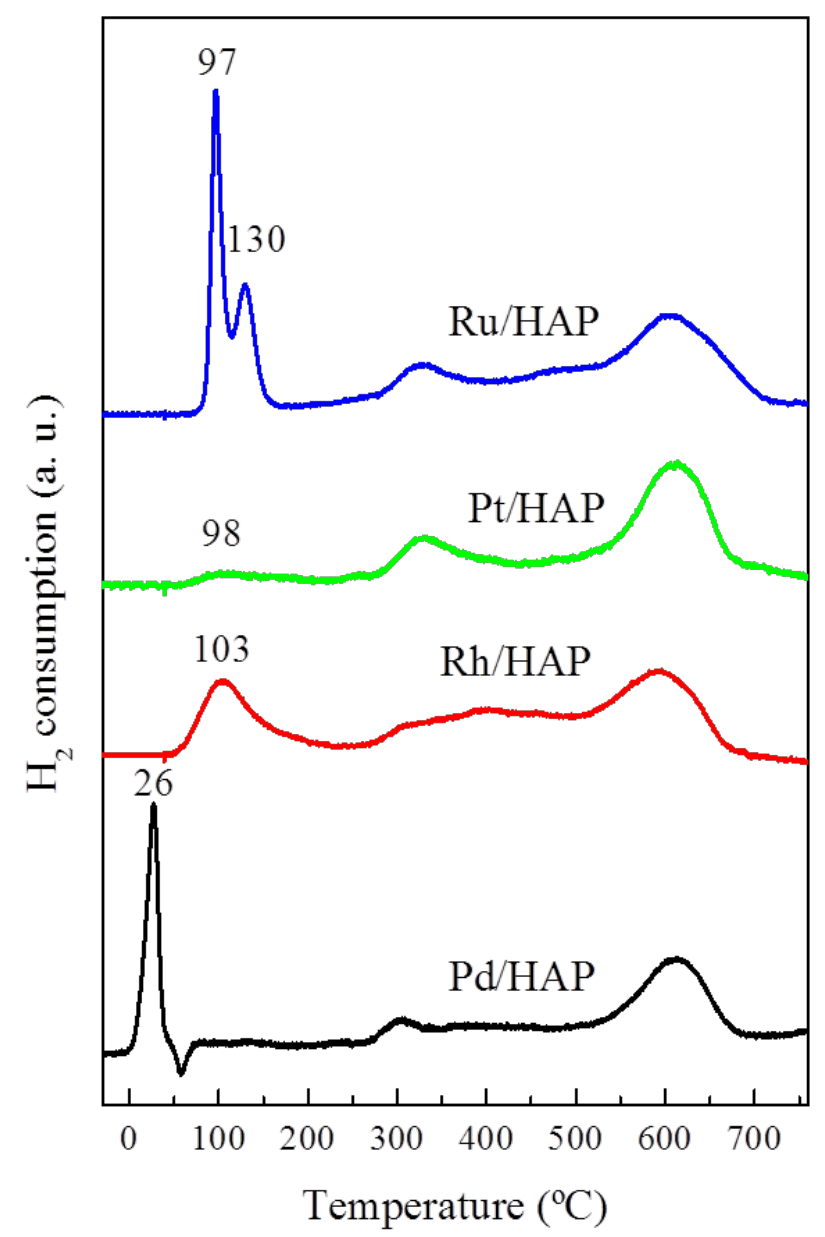

Figure 3. $\mathrm{H}_{2}$-TPR diagrams for the noble metal catalysts.

Figure 4 includes TEM images of the catalysts reduced at $400{ }^{\circ} \mathrm{C}$. In all cases, quasispherical metallic particles can be observed. Table 2 summarizes the average particle size and the dispersion of supported samples. Interestingly, the estimated average size $\left(\mathrm{d}_{\mathrm{M}}\right)$ is found to depend on the nature of the active metal following this order: $\mathrm{d}_{\mathrm{Rh}}(1 \mathrm{~nm})<\mathrm{d}_{\mathrm{Pt}}(2 \mathrm{~nm})<\mathrm{d}_{\mathrm{Pd}}(4.6 \mathrm{~nm})<\mathrm{d}_{\mathrm{Ru}}(8.3 \mathrm{~nm})$. Although the dispersion data estimated by $\mathrm{CO}$ chemisorptions (Table 2) differ from those given by TEM, the general tendency is found to be maintained, irrespective of the technique used. 

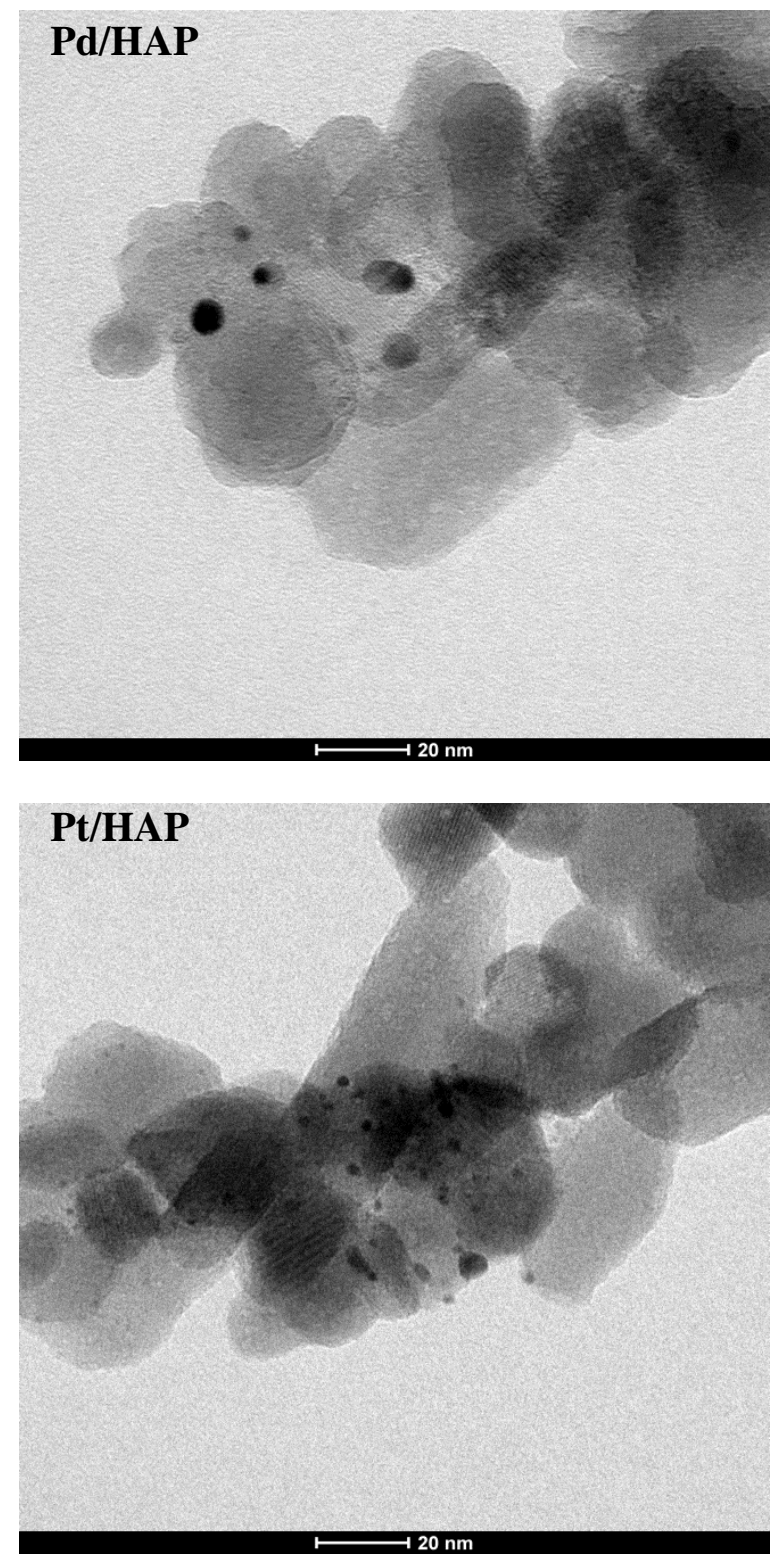
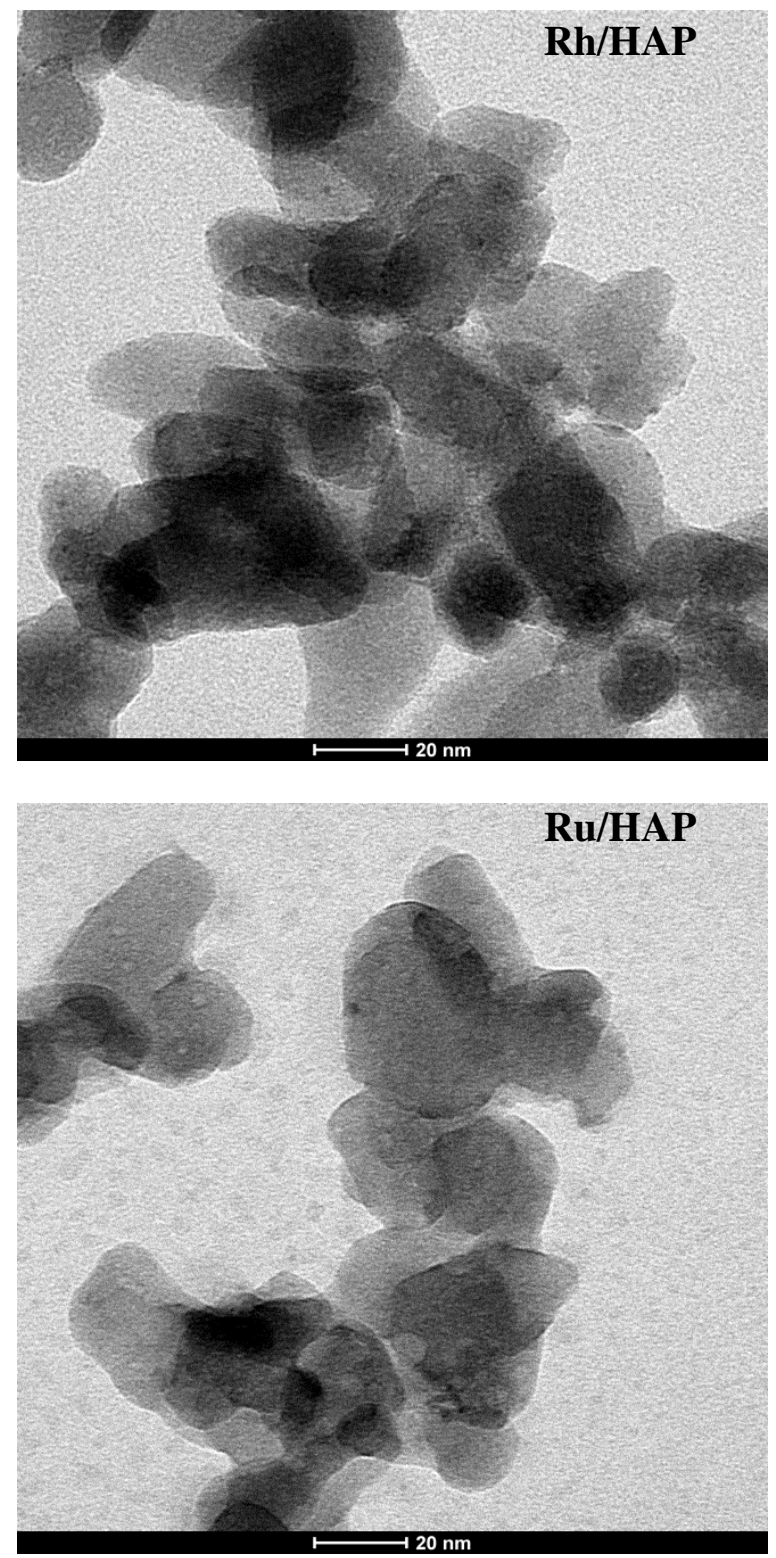

Figure 4. TEM micrographs of the reduced noble metal catalysts.

Table 2. CO chemisorption, TEM, and catalytic activity data for the noble metal catalysts.

\begin{tabular}{|c|c|c|c|c|c|c|c|}
\hline \multirow{2}{*}{ Catalyst } & \multirow{2}{*}{$\begin{array}{l}\text { CO Chem } \\
D_{\text {Chem }} \%\end{array}$} & \multicolumn{2}{|c|}{ TEM } & \multicolumn{4}{|c|}{ Methane Oxidation Reaction (b) } \\
\hline & & $\mathrm{D}_{\mathrm{TEM}}, \%$ & $\mathrm{~d}_{\mathrm{M}}, \mathrm{nm}$ & $\mathbf{T}_{10}$ & $\mathbf{T}_{50}$ & $\mathbf{T}_{100}$ & $\mathrm{Ea}, \mathrm{kJ} / \mathrm{mol}$ \\
\hline $\mathrm{Pd} / \mathrm{HAP}$ & $29(22)^{(a)}$ & 18.6 & 4.6 & 300 & 375 & 475 & 77 \\
\hline Rh/HAP & $96(81)^{(a)}$ & 73 & 1 & 300 & 390 & 500 & 76 \\
\hline $\mathrm{Pt} / \mathrm{HAP}$ & 47 & 41.2 & 2 & 430 & - & - & 105 \\
\hline $\mathrm{Ru} / \mathrm{HAP}$ & 4.7 & 8.2 & 8.3 & 500 & - & - & 95 \\
\hline
\end{tabular}

(a) Data corresponding to the catalysts submitted to three cycles of the reaction (Figure 9). ${ }^{(b)}$ Data extracted from Figure 6.

The results corresponding to the OSC experiments, in the temperature range between 350 and $500{ }^{\circ} \mathrm{C}$, are displayed in Figure 5. These studies provide valuable information about the ability of the reduced catalysts to be re-oxidized. It should be noted that the samples were pretreated under a reducing atmosphere $\left(5 \% \mathrm{H}_{2} / \mathrm{Ar}\right)$ at $500{ }^{\circ} \mathrm{C}$ for $1 \mathrm{~h}$. As expected, over all analyzed samples the OSC activity increases with the temperature. Moreover, a comparison of the OSC values for the different catalysts reveals that they follow this general 
trend: $\mathrm{Rh} / \mathrm{HAP}>\mathrm{Pd} / \mathrm{HAP}>\mathrm{Pt} / \mathrm{HAP}>\mathrm{Ru} / \mathrm{HAP}$. Interestingly, at $500{ }^{\circ} \mathrm{C}$, the oxygen uptakes measured on the Pd and Rh catalysts (23.1 and $36.1 \mu$ mol $_{\mathrm{O} 2} \mathrm{~g}^{-1}$, respectively) are very similar to the theoretical values required for the formation of stoichiometric $\mathrm{PdO}$ and $\mathrm{Rh}_{2} \mathrm{O}_{3}$ phases, respectively. However, regardless of the analysis temperature, the $\mathrm{Pt}$ and $\mathrm{Ru}$ catalysts show very low OSC. Despite increasing the temperature to $500{ }^{\circ} \mathrm{C}$, the amounts of stored oxygen do not exceed 6.1 and $3.1 \mu \mathrm{mol}_{\mathrm{O} 2} \mathrm{~g}^{-1}$, respectively, thereby suggesting that their complete oxidation is a very slow process which probably requires higher temperatures. Instead, this low OSC activity can be related to the oxygen storage sites located at the near surface only.

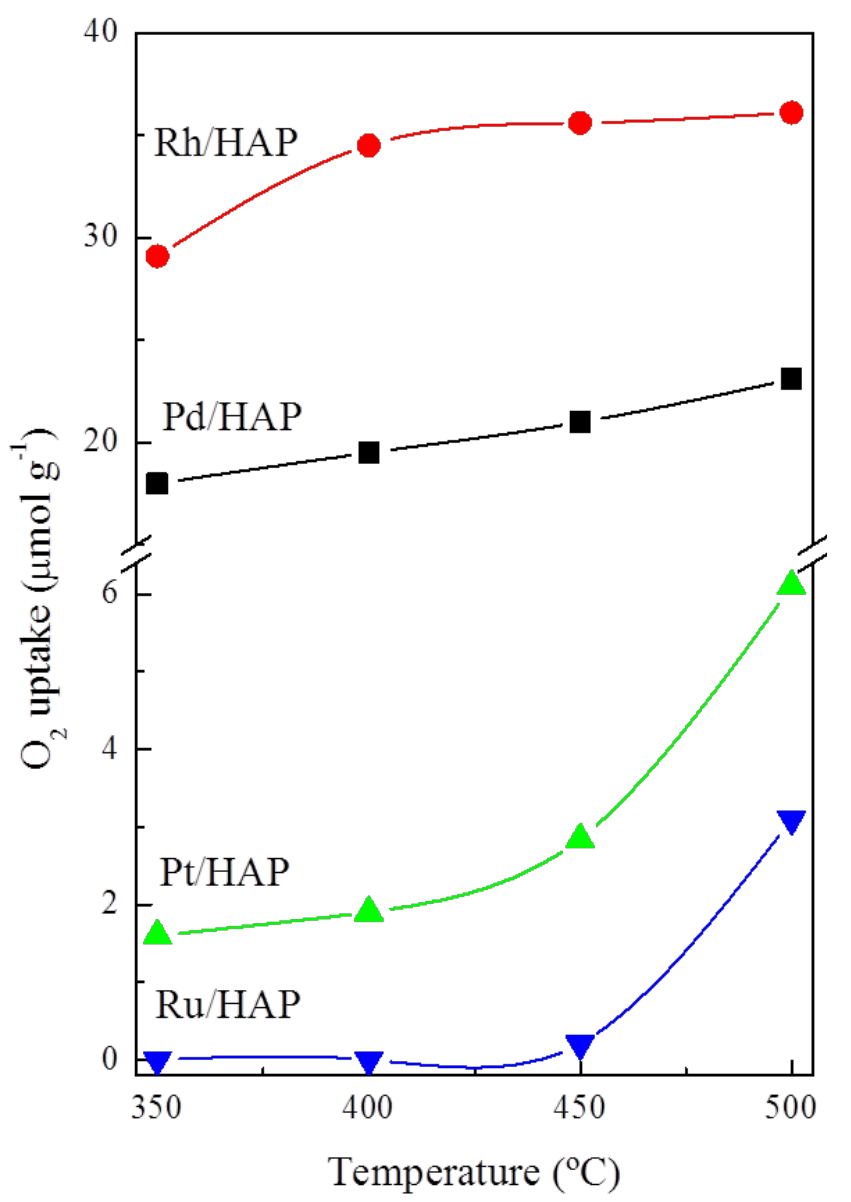

Figure 5. OSC studies on the noble metal catalysts.

\subsection{Catalytic Activity}

Figure 6 displays the light-off curves of the prepared catalysts in the methane oxidation reaction. Note that carbon dioxide was the main carbonaceous product detected and only negligible amounts of carbon monoxide could be observed. As expected, the HAP bare support shows a low activity, which does not reach $4 \%$ at $500{ }^{\circ} \mathrm{C}$. Over the Pd/HAP and $\mathrm{Rh} / \mathrm{HAP}$ samples, methane conversion starts at $225^{\circ} \mathrm{C}$ and increases slowly with the temperature to reach $30 \%$ at $350{ }^{\circ} \mathrm{C}$. At higher temperatures, the Pd/HAP catalyst becomes more efficient than the Rh/HAP sample. Nevertheless, over the latter the total oxidation of methane can be reached when raising the reaction temperature to $500{ }^{\circ} \mathrm{C}$. However, the $\mathrm{Pt} / \mathrm{HAP}$ and $\mathrm{Ru} / \mathrm{HAP}$ samples exhibit a poorer performance, because methane oxidation is only visible above $350{ }^{\circ} \mathrm{C}$ and the conversion levels at $500{ }^{\circ} \mathrm{C}$ do not exceed $35 \%$ and $15 \%$, respectively. Thus, the catalyst efficiency follows this general trend: $\mathrm{Pd} / \mathrm{HAP}>\mathrm{Rh} / \mathrm{HAP}>$ $\mathrm{Pt} / \mathrm{HAP}>\mathrm{Ru} / \mathrm{HAP}$. This is in good agreement with the literature data, in which palladium catalysts are generally regarded as the most promising candidates for complete methane oxidation [30-33]. For instance, a similar trend was reported by Oh et al. [30] in their 
study on the activity of $\gamma-\mathrm{Al}_{2} \mathrm{O}_{3}$-supported catalysts under both oxidizing and reducing conditions $(\mathrm{Pd}>\mathrm{Rh}>\mathrm{Pt})$. On the other hand, when subjected to a second light-off experiment, the $\mathrm{Pd} / \mathrm{HAP}$ and $\mathrm{Rh} / \mathrm{HAP}$ catalysts show a moderate deactivation process (Figure S2). Thereafter, they maintain a stable performance.

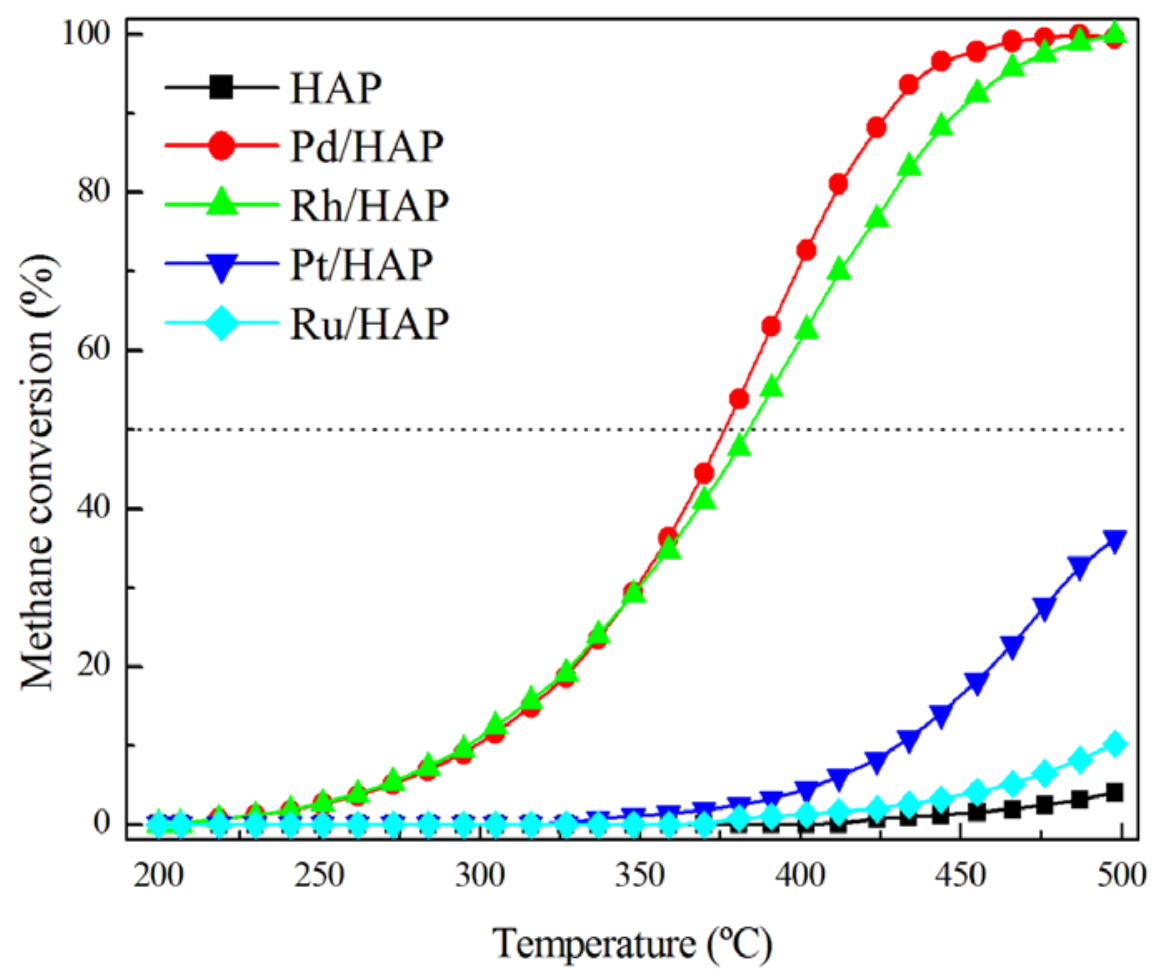

Figure 6. Comparison of the performance of the prepared catalysts in the methane oxidation. The reaction mixture was composed of $1 \% \mathrm{CH}_{4}, 20 \% \mathrm{O}_{2}$, and $79 \% \mathrm{He}$.

Because there is no correlation between the performance and the metallic dispersion, it can be concluded that the dependence of methane oxidation on the metallic particle size, spread on the HAP support, is secondary. Instead, the superiority of Pd/HAP and $\mathrm{Rh} / \mathrm{HAP}$ samples can be explained by their greater OSC activity. This high tendency to be re-oxidized probably generates more active metal oxides. Previous reports demonstrated that the activity of noble metals in methane oxidation proceed through the Mars-Van Krevelen mechanism, in which their ability to undergo redox processes under the reaction mixture is a determining factor $[13,31,32]$. Accordingly, the Ru/HAP and Pt/HAP catalysts showed a low activity, because a large fraction of the supported metal probably remains in reduced forms after being exposed to the reaction mixture, even in the presence of a high concentration of oxygen ( $20 \%)$.

The apparent activation energy $\left(E_{a}\right)$ values were estimated assuming a first order reaction. Thus, a linear correlation can be observed between $\ln \left[-\ln \left(1-\mathrm{X}_{\mathrm{CH} 4}\right)\right]$ and $1 / \mathrm{T}$ (Figure 7). As expected, the most active catalysts (Pd/HAP and Rh/HAP) show the lowest $\mathrm{E}_{\mathrm{a}}$ values $\left(76-77 \mathrm{~kJ} \mathrm{~mol}^{-1}\right.$ ) compared with those estimated over Pt/HAP and Ru/HAP catalysts (105 and $95 \mathrm{~kJ} \mathrm{~mol}^{-1}$, respectively) (Table 2). Note that our estimated values are comparable to those reported over noble metals supported on different materials [31-35]. 


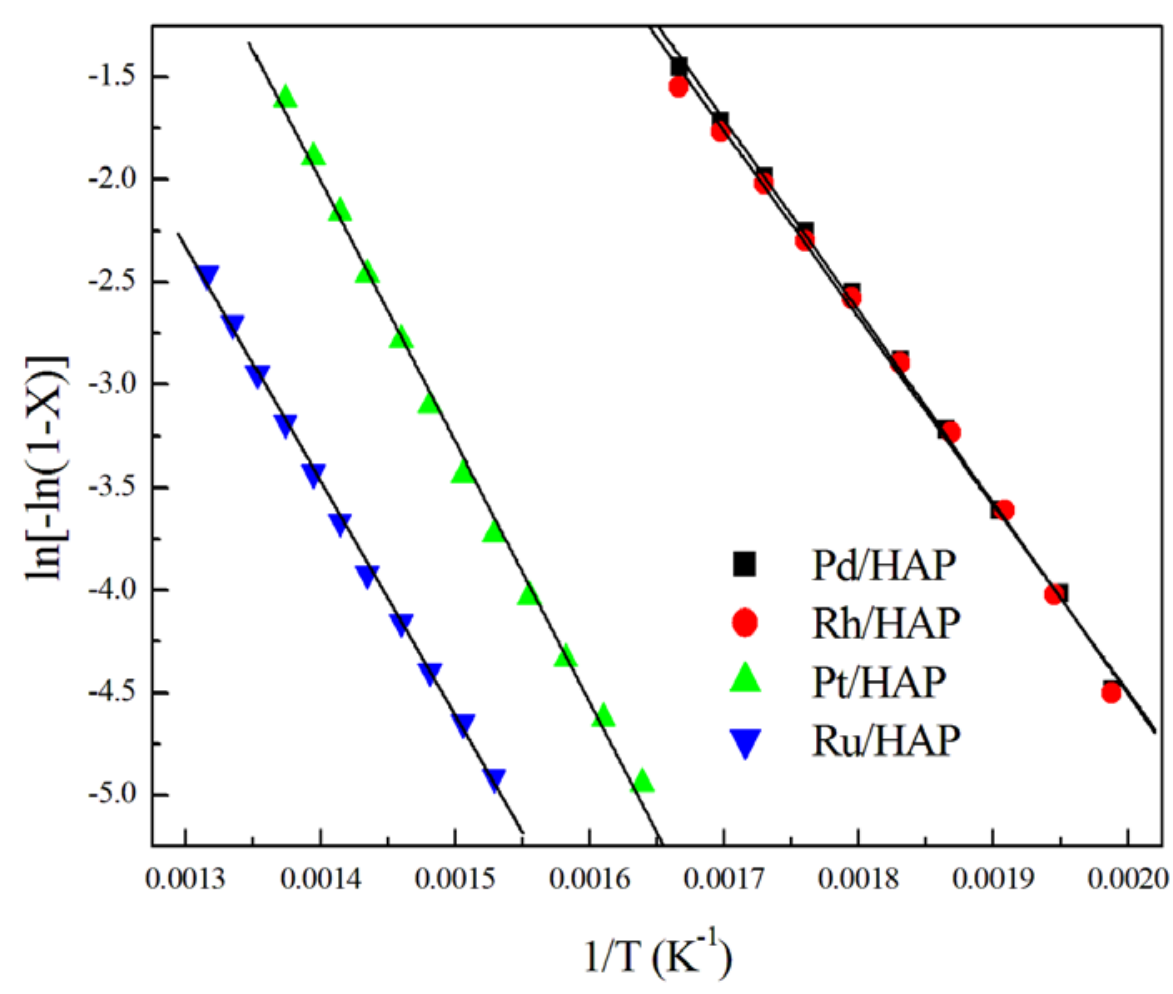

Figure 7. Arrhenius plots for methane oxidation over the noble metal catalysts.

Given the promising performance of the Pd/HAP and Rh/HAP samples, additional experiments were carried out to study the effect of the addition of $\mathrm{H}_{2} \mathrm{O}$ and $\mathrm{CO}_{2}$ on their catalytic efficiency (Figure 8). Irrespective of the reaction mixture composition $\left(\mathrm{CH}_{4} / \mathrm{O}_{2}\right.$, $\mathrm{CH}_{4} / \mathrm{O}_{2} / \mathrm{CO}_{2}, \mathrm{CH}_{4} / \mathrm{O}_{2} / \mathrm{H}_{2} \mathrm{O}$, and $\mathrm{CH}_{4} / \mathrm{O}_{2} / \mathrm{CO}_{2} / \mathrm{H}_{2} \mathrm{O}$ ), the Pd/HAP sample exhibits a higher activity than the $\mathrm{Rh} / \mathrm{HAP}$ catalyst. The addition of $\mathrm{CO}_{2}$ causes a negative effect on the behavior of the two catalysts, which can be associated with the accumulation of carbonates on the catalyst surface [36]. However, the deactivation process is found to be more profound with the addition of water. At $400{ }^{\circ} \mathrm{C}$, feeding water provokes a significant drop in the conversion over the Pd/HAP sample (from $75 \%$ to $25 \%$ ). Similarly, over the $\mathrm{Rh} / \mathrm{HAP}$ catalyst the conversion decreases from $63 \%$ to $15 \%$. According to previous studies, the presence of water causes a severe hydroxylation of the surface's active sites, which inhibits the re-oxidation of the noble metal catalysts [37-42]. For instance, the deactivation of $\mathrm{Pd}$ by water was described as a reversible process involving the formation of the inactive $\mathrm{Pd}(\mathrm{OH})_{2}$ phase $\left(\mathrm{PdO}+\mathrm{H}_{2} \mathrm{O} \leftrightarrow \mathrm{Pd}(\mathrm{OH})_{2}\right)$ [37-39,41]. Interestingly, the extent of deactivation by water appears to be much lower at higher temperatures. For instance, at $500{ }^{\circ} \mathrm{C}$, a slight decrease in the Pd/HAP activity can be observed, from $100 \%$ to $95 \%$. In the case of the Rh/HAP catalyst, the effect of water is somewhat more appreciable because the conversion levels decrease from $100 \%$ to $84 \%$ at $500{ }^{\circ} \mathrm{C}$. A simultaneous feeding of water and $\mathrm{CO}_{2}$ influences the performance of the two catalysts via different pathways. Over the Pd/HAP sample, the conversion values are slightly lower than those observed when adding water alone. By contrast, in the presence of water and $\mathrm{CO}_{2}$ the activity of the Rh/HAP sample is higher than that observed when adding water alone. It should be highlighted that in all cases the extent of the inhibiting effect of water and $\mathrm{CO}_{2}$ is significantly lower when working at high temperatures $\left(>475{ }^{\circ} \mathrm{C}\right)$. Florén et al. [36] reported a similar effect in their study on the activity of a $\mathrm{Pd} / \mathrm{Al}_{2} \mathrm{O}_{3}$ catalyst in a methane oxidation reaction. They associated this behavior, observed at high temperatures, with the low coverage of bicarbonates and adsorbed water, which hinder the dissociative adsorption of methane on the $\mathrm{Pd}-\mathrm{O}$ site pair. 

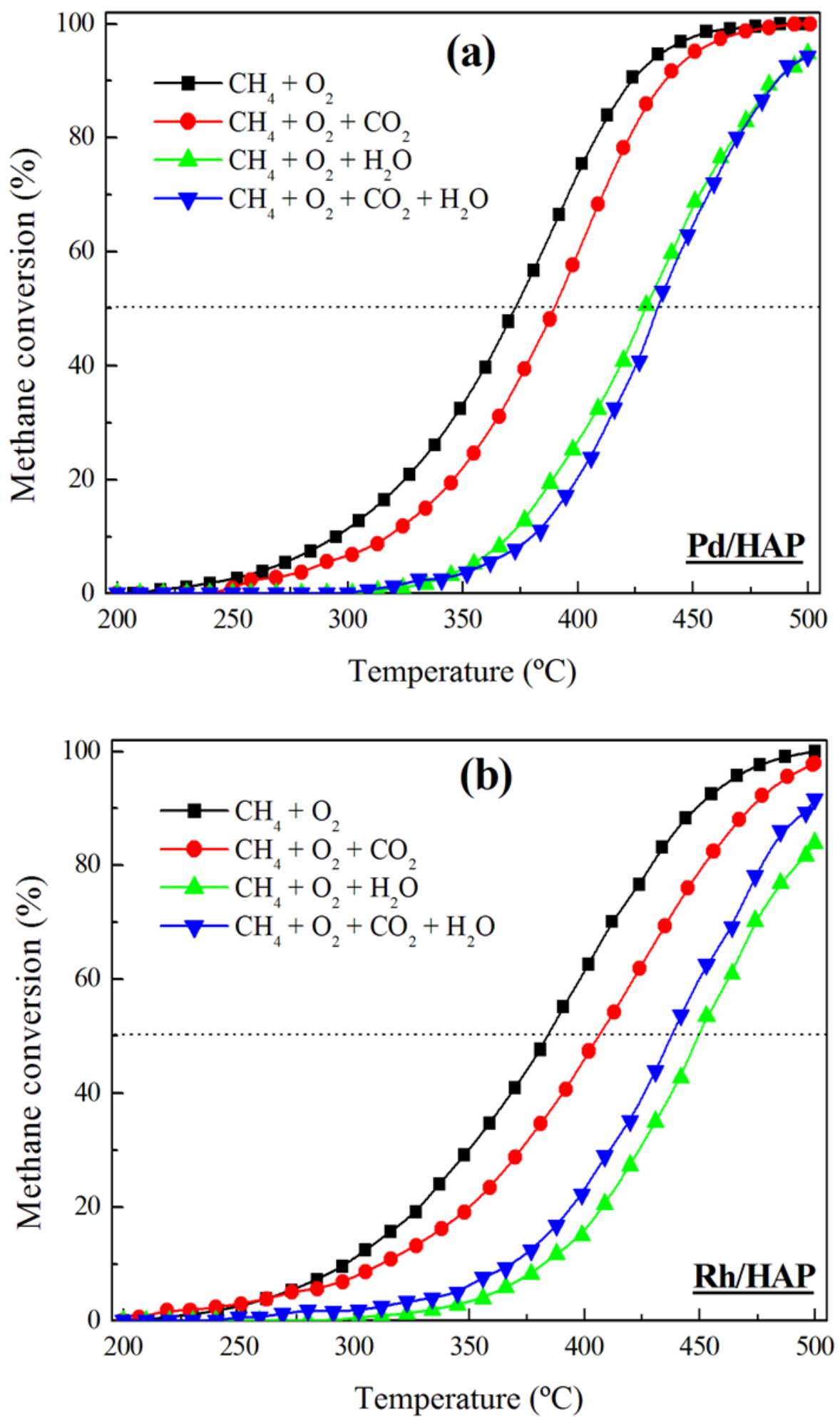

Figure 8. Influence of the reaction mixture composition on the performance of (a) Pd/HAP and (b) $\mathrm{Rh} / \mathrm{HAP}$ catalysts in methane oxidation.

Figure 9 shows the evolution of the activity of the $\mathrm{Pd}$ and $\mathrm{Rh}$ catalysts submitted to three consecutive cycles with the realistic reaction mixture, including water and $\mathrm{CO}_{2}$. With reference to the first heating ramp, the activity significantly decreases during the subsequent heating step, because $\mathrm{T}_{50}$ increases from 433 to $441^{\circ} \mathrm{C}$ and from 436 to $449^{\circ} \mathrm{C}$ over the Pd/HAP and Rh/HAP catalysts, respectively. The CO chemisorption data for the spent catalysts (Table 2) suggest that the observed deactivation can be related to a loss in 
the number of the exposed active sites. Thereafter, the two catalysts appear to maintain a stable performance, in which a virtually negligible difference could be observed between the second and the third heating cycles.
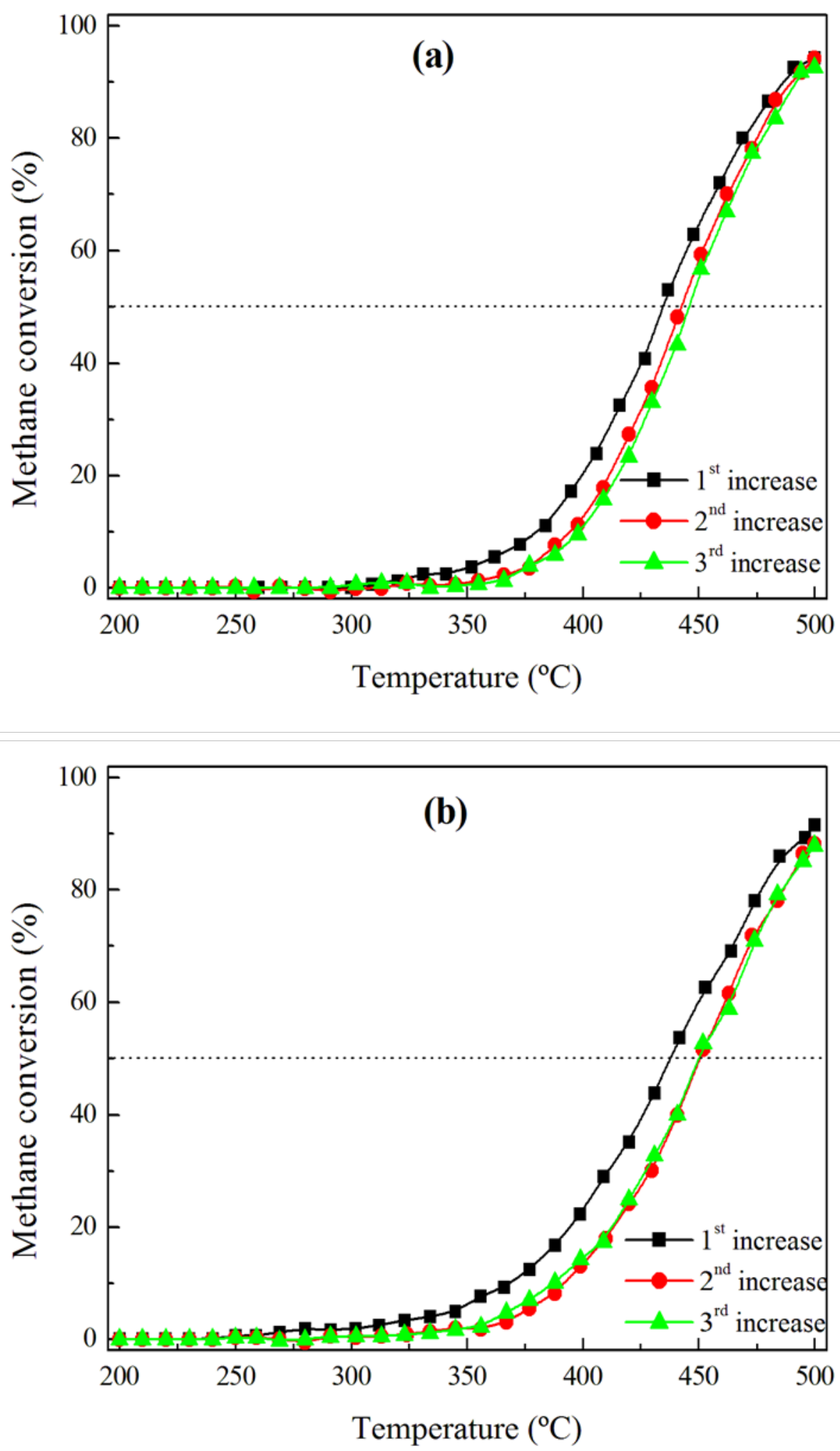

Figure 9. Activity of (a) Pd/HAP and (b) Rh/HAP catalysts submitted to three cycles of a realistic methane oxidation mixture: $1 \% \mathrm{CH}_{4}, 20 \% \mathrm{O}_{2}, 10 \% \mathrm{H}_{2} \mathrm{O}$, and $10 \% \mathrm{CO}_{2}$. 


\section{Conclusions}

The methane oxidation reaction was investigated over various HAP supported noble metal catalysts. $\mathrm{H}_{2}$-TPR analysis indicated that, among all analyzed samples, the $\mathrm{Pt}$ catalyst exhibited the lowest reducibility. TEM and CO chemisorption studies evidenced the deposition of highly dispersed metallic Rh and Pt particles, which were significantly smaller than Pd and Ru particles. Furthermore, the OSC data revealed that although Pd and $\mathrm{Rh}$ catalysts could be easily re-oxidized, the re-oxidation of $\mathrm{Pt}$ and $\mathrm{Ru}$ catalysts appeared to be a slow process, resulting in small numbers of metal oxide active sites.

The catalytic results of the methane oxidation over the series of noble metals showed a better efficiency of the Pd/HAP and Rh/HAP catalysts compared with Pt/HAP and $\mathrm{Ru} / \mathrm{HAP}$ samples. The superiority of the former was assigned to their high ability to undergo the redox process under the reaction mixture conditions. Feeding water and $\mathrm{CO}_{2}$ was found to have a negative effect, which was more pronounced in the presence of water, on the activity of $\mathrm{Pd}$ and $\mathrm{Rh}$ catalysts. However, the inhibiting effect of $\mathrm{CO}_{2}$ and $\mathrm{H}_{2} \mathrm{O}$ decreased by increasing the reaction temperature.

Supplementary Materials: The following are available online at https:/ / www.mdpi.com/article/10 $.3390 / \mathrm{ma14133612/s1}$, Table S1. XRD data for the noble metal catalysts; Figure S1. N 2 physisorption isotherms for the prepared catalysts; Figure S2. Activity of (a) Pd/HAP and (b) Rh/HAP catalysts submitted to three cycles of methane oxidation reaction.

Author Contributions: Conceptualization, Z.B. and R.L.-F.; methodology, Z.B.; software, Z.B. validation, Z.B. and R.L.-F.; formal analysis, Z.B.; investigation, Z.B.; resources, Z.B.; data curation, Z.B.; writing-original draft preparation, Z.B.; writing-review and editing, Z.B.; visualization, R.L.-F. and J.I.G.-O.; supervision, J.R.G.-V.; project administration, Z.B., B.d.R. and R.L.-F.; funding acquisition, Z.B., J.R.G.-V., B.d.R., J.I.G.-O. and R.L.-F. All authors have read and agreed to the published version of the manuscript.

Funding: This research was funded by Ministerio de Economía y Competitividad (CTQ201573219-JIN (AEI/FEDER/UE)), Spanish ministry of Science and Innovation (PID2019-107105RB-I00 AEI/FEDER, UE) and Basque Government (GIC IT-1297-19).

Institutional Review Board Statement: Not applicable.

Informed Consent Statement: Not applicable.

Data Availability Statement: Data sharing is not applicable to this article.

Acknowledgments: The financial support for this work provided by Ministerio de Economía y Competitividad (CTQ2015-73219-JIN (AEI/FEDER/UE)), Spanish ministry of Science and Innovation (PID2019-107105RB-I00 AEI/FEDER, UE) and Basque Government (GIC IT-1297-19) is gratefully acknowledged. Similarly, the technical support provided by SGIker (UPV/EHU) is gratefully acknowledged.

Conflicts of Interest: The authors declare no conflict of interest.

\section{References}

1. Boukha, Z.; Kacimi, M.; Ziyad, M.; Ensuque, A.; Bozon-Verduraz, F. Comparative study of catalytic activity of Pd loaded hydroxyapatite and fluoroapatite in butan-2-ol conversion and methane oxidation. J. Mol. Catal. A Chem. 2007, 270, 205-213. [CrossRef]

2. Friberg, I.; Sadokhina, N.; Olsson, L. The effect of Si / Al ratio of zeolite supported Pd for complete $\mathrm{CH}_{4}$ oxidation in the presence of water vapor and $\mathrm{SO}_{2}$. Appl. Catal. B Environ. 2019, 250, 117-131. [CrossRef]

3. Friberg, I.; Sadokhina, N.; Olsson, L. Complete methane oxidation over Ba modified $\mathrm{Pd} / \mathrm{Al}_{2} \mathrm{O}_{3}$ : The effect of water vapor. Appl. Catal. B Environ. 2018, 231, 242-250. [CrossRef]

4. Gholami, R.; Alyani, M.; Smith, K.J. Deactivation of Pd catalysts by water during low temperature methane oxidation relevant to natural gas vehicle converters. Catalysts 2015, 5, 561-594. [CrossRef]

5. Mihai, O.; Smedler, G.; Nylén, U.; Olofsson, M.; Olsson, L. The effect of water on methane oxidation over Pd/Al2O3 under lean, stoichiometric and rich conditions. Catal. Sci. Technol. 2017, 7, 3084-3096. [CrossRef]

6. Petrov, A.W.; Ferri, D.; Krumeich, F.; Nachtegaal, M.; Van Bokhoven, J.A.; Kröcher, O. Stable complete methane oxidation over palladium based zeolite catalysts. Nat. Commun. 2018, 9, 2545. [CrossRef] [PubMed] 
7. Boukha, Z.; Choya, A.; Cortés-Reyes, M.; de Rivas, B.; Alemany, L.J.; González-Velasco, J.R.; Gutiérrez-Ortiz, J.I.; López-Fonseca, $\mathrm{R}$. Influence of the calcination temperature on the activity of hydroxyapatite-supported palladium catalyst in the methane oxidation reaction. Appl. Catal. B Environ. 2020, 277, 119280. [CrossRef]

8. Petrov, A.W.; Ferri, D.; Kröcher, O.; Van Bokhoven, J.A. Design of stable palladium-based zeolite catalysts for complete methane oxidation by postsynthesis zeolite modification. ACS Catal. 2019, 9, 2303-2312. [CrossRef]

9. Yoshida, H.; Nakajima, T.; Yazawa, Y.; Hattori, T. Support effect on methane combustion over palladium catalysts. Appl. Catal. B Environ. 2007, 71, 70-79. [CrossRef]

10. Kul Ryu, C.; Wong Ryoo, M.; Soo Ryu, I.; Kyu Kang, S. Catalytic combustion of methane over supported bimetallic Pd catalysts: Effects of Ru or Rh addition. Catal. Today 1999, 47, 141-147. [CrossRef]

11. Stoian, M.; Rogé, V.; Lazar, L.; Maurer, T.; Védrine, J.C.; Marcu, I.-C.; Fechete, I. Total oxidation of methane on oxide and mixed oxide ceria-containing catalysts. Catalysts 2021, 11, 427. [CrossRef]

12. Colussi, S.; Trovarelli, A.; Cristiani, C.; Lietti, L.; Groppi, G. The influence of ceria and other rare earth promoters on palladiumbased methane combustion catalysts. Catal. Today 2012, 180, 124-130. [CrossRef]

13. Cullis, C.F.; Willatt, B.M. Oxidation of methane over supported precious metal catalysts. J. Catal. 1983, 83, 267-285. [CrossRef]

14. Boukha, Z.; Ayastuy, J.L.; Cortés-Reyes, M.; Alemany, L.J.; González-Velasco, J.R.; Gutiérrez-Ortiz, M.A. Catalytic performance of $\mathrm{Cu}$ /hydroxyapatite catalysts in $\mathrm{CO}$ preferential oxidation in $\mathrm{H}_{2}$-rich stream. Int. J. Hydrogen Energ. 2019, 44, 12649-12660. [CrossRef]

15. Boukha, Z.; Ayastuy, J.L.; Cortés-Reyes, M.; Alemany, L.J.; Gutiérrez-Ortiz, M.A.; González-Velasco, J.R. Catalytic properties of cobalt-promoted Pd/HAP catalyst for CO-cleanup of H2-rich stream. Int. J. Hydrogen Energ. 2018, 43, 16949-16958. [CrossRef]

16. Boukha, Z.; Ayastuy, J.L.; González-Velasco, J.R.; Gutiérrez-Ortiz, M.A. Water-gas shift reaction over a novel Cu-ZnO/HAP formulation: Enhanced catalytic performance in mobile fuel cell applications. Appl. Catal. A Gen. 2018, 566, 1-14. [CrossRef]

17. Boukha, Z.; Ayastuy, J.L.; González-Velasco, J.R.; Gutiérrez-Ortiz, M.A. CO elimination processes over promoter-free hydroxyapatite supported palladium catalysts. Appl. Catal. B Environ. 2017, 201, 189-201. [CrossRef]

18. Boukha, Z.; Gil-Calvo, M.; de Rivas, B.; González-Velasco, J.R.; Gutiérrez-Ortiz, J.I.; López-Fonseca, R. Behaviour of Rh supported on hydroxyapatite catalysts in partial oxidation and steam reforming of methane: On the role of the speciation of the Rh particles. Appl. Catal. A Gen. 2018, 556, 191-203. [CrossRef]

19. Boukha, Z.; González-Prior, J.; de Rivas, B.; González-Velasco, J.R.; López-Fonseca, R.; Gutiérrez-Ortiz, J.I. Pd supported catalyst for gas-phase 1,2-dichloroethane abatement: Efficiency and high selectivity towards oxygenated products. J. Ind. Eng. Chem. 2018, 57, 77-88. [CrossRef]

20. Boukha, Z.; González-Prior, J.; Rivas, B.; González-Velasco, J.R.; López-Fonseca, R.; Gutiérrez-Ortiz, J.I. Synthesis, characterisation and behaviour of $\mathrm{Co} /$ hydroxyapatite catalysts in the oxidation of 1,2-dichloroethane. Appl. Catal. B Environ. 2016, 190, 125-136. [CrossRef]

21. Boukha, Z.; González-Velasco, J.R.; Gutiérrez-Ortiz, M.A. Exceptional performance of gold supported on fluoridated hydroxyapatite catalysts in $\mathrm{CO}$-cleanup of $\mathrm{H}_{2}$-rich stream: High activity and resistance under PEMFC operation conditions. Appl. Catal. $B$ Environ. 2021, 292, 120142. [CrossRef]

22. Boukha, Z.; González-Velasco, J.R.; Gutiérrez-Ortiz, M.A. Platinum supported on lanthana-modified hydroxyapatite samples for realistic WGS conditions: On the nature of the active species, kinetic aspects and the resistance to shut-down/start-up cycles. Appl. Catal. B Environ. 2020, 270, 118851. [CrossRef]

23. Boukha, Z.; Kacimi, M.; Pereira, M.F.R.; Faria, J.L.; Figueiredo, J.L.; Ziyad, M. Methane dry reforming on Ni loaded hydroxyapatite and fluoroapatite. Appl. Catal. A-Gen. 2007, 317, 299-309. [CrossRef]

24. Boukha, Z.; Yeste, M.P.; Cauqui, M.Á.; González-Velasco, J.R. Influence of Ca/P ratio on the catalytic performance of $\mathrm{Ni}$ /hydroxyapatite samples in dry reforming of methane. Appl. Catal. A-Gen. 2019, 580, 34-45. [CrossRef]

25. Lietz, G.; Lieske, H.; Spindler, H.; Hanke, W.; Völter, J. Reactions of platinum in oxygen- and hydrogen-treated $\mathrm{Pt}_{\mathrm{t}} \gamma-\mathrm{Al}_{2} \mathrm{O}_{3}$ catalysts. II. Ultraviolet-visible studies, sintering of platinum, and soluble platinum. J. Catal. 1983, 81, 17-25. [CrossRef]

26. Xiao, Z.; Jiang, X.; Li, B.; Liu, X.; Huang, X.; Zhang, Y.; Ren, Q.; Luo, J.; Qin, Z.; Hu, J. Hydrous RuO 2 nanoparticles as an efficient NIR-light induced photothermal agent for ablation of cancer cells in vitro and in vivo. Nanoscale 2015, 7, 11962-11970. [CrossRef] [PubMed]

27. Varga, E.; Baán, K.; Samu, G.F.; Erdőhelyi, A.; Oszkó, A.; Kónya, Z.; Kiss, J. The effect of Rh on the interaction of Co with $\mathrm{Al}_{2} \mathrm{O}_{3}$ and $\mathrm{CeO}_{2}$ supports. Catal. Lett. 2016, 146, 1800-1807. [CrossRef]

28. Jones, D.R.; Iqbal, S.; Kondrat, S.A.; Lari, G.M.; Miedziak, P.J.; Morgan, D.J.; Parker, S.F.; Hutchings, G.J. An investigation of the effect of carbon support on ruthenium/carbon catalysts for lactic acid and butanone hydrogenation. Phys. Chem. Chem. Phys. 2016, 18, 17259-17264. [CrossRef]

29. Lanza, R.; Järås, S.G.; Canu, P. Partial oxidation of methane over supported ruthenium catalysts. Appl. Catal. A-Gen. 2007, 325, 57-67. [CrossRef]

30. Oh, S.H.; Mitchell, P.J.; Siewert, R.M. Methane oxidation over alumina-supported noble metal catalysts with and without cerium additives. J. Catal. 1991, 132, 287-301. [CrossRef]

31. Hurtado, P.; Ordóñez, S.; Sastre, H.; Díez, F.V. Development of a kinetic model for the oxidation of methane over $\mathrm{Pd} / \mathrm{Al}_{2} \mathrm{O}_{3}$ at dry and wet conditions. Appl. Catal. B Environ. 2004, 51, 229-238. [CrossRef] 
32. Todorova, S.; Naydenov, A.; Kolev, H.; Ivanov, G.; Ganguly, A.; Mondal, S.; Saha, S.; Ganguli, A.K. Reaction kinetics and mechanism of complete methane oxidation on $\mathrm{Pd} / \mathrm{Mn}_{2} \mathrm{O}_{3}$ catalyst. React. Kinet. Mech. Catal. 2018, 123, 585-605. [CrossRef]

33. Wonoputri, V.; Effendy, M.; Wibisono Budhi, Y.; Bindar, Y. Determination of kinetic parameters for methane oxidation over $\mathrm{Pt} / \gamma-\mathrm{Al}_{2} \mathrm{O}_{3}$ in a fixed-bed reactor. J. Eng. Technol. Sci. 2013, 45 B, 193-206. [CrossRef]

34. Garetto, T.F.; Apesteguía, C.R. Oxidative catalytic removal of hydrocarbons over $\mathrm{Pt} / \mathrm{Al}_{2} \mathrm{O}_{3}$ catalysts. Catal. Today 2000, 62, 189-199. [CrossRef]

35. Okal, J.; Zawadzki, M. Catalytic combustion of methane over ruthenium supported on zinc aluminate spinel. Appl. Catal. A Gen. 2013, 453, 349-357. [CrossRef]

36. Florén, C.-R.; Van Den Bossche, M.; Creaser, D.; Grönbeck, H.; Carlsson, P.; Korpi, H.; Skoglundh, M. Modelling complete methane oxidation over palladium oxide in a porous catalyst using first-principles surface kinetics. Catal. Sci. Technol. 2018, 8 , 508-520. [CrossRef]

37. Gélin, P.; Primet, M. Complete oxidation of methane at low temperature over noble metal based catalysts: A review. Appl. Catal. B Environ. 2002, 39, 1-37. [CrossRef]

38. Kikuchi, R.; Maeda, S.; Sasaki, K.; Wennerström, S.; Eguchi, K. Low-temperature methane oxidation over oxide-supported Pd catalysts: Inhibitory effect of water vapor. Appl. Catal. A Gen. 2002, 232, 23-28. [CrossRef]

39. Eriksson, S.; Boutonnet, M.; Järås, S. Catalytic combustion of methane in steam and carbon dioxide-diluted reaction mixtures. Appl. Catal. A Gen. 2006, 312, 95-101. [CrossRef]

40. Mao, Q.; van Duin, A.C.T.; Luo, K.H. Investigation of methane oxidation by palladium-based catalyst via ReaxFF molecular dynamics simulation. Proc. Combust. Inst. 2017, 36, 4339-4346. [CrossRef]

41. Li, X.; Wang, X.; Roy, K.; Van Bokhoven, J.A.; Artiglia, L. Role of Water on the structure of palladium for complete oxidation of methane. ACS Catal. 2020, 10, 5783-5792. [CrossRef]

42. Zhang, Y.; Glarborg, P.; Johansen, K.; Andersson, M.P.; Torp, T.K.; Jensen, A.D.; Christensen, J.M. A rhodium-based methane oxidation catalyst with high tolerance to $\mathrm{H}_{2} \mathrm{O}$ and $\mathrm{SO}_{2}$. ACS Catal. 2020, 10, 1821-1827. [CrossRef] 